\title{
Content Analysis of Entrepreneurship Education in Primary and Secondary School Textbooks
}

\author{
Tshewang Dorji
}

*Dechencholing Higher Secondary School, Thimphu Thromde, Bhutan

Ministry of Education

E-mail: tshewangtshewang@gmail.com

\section{Article Info}

Received : January 1, 2021

Revised : April 12, 2021

Accepted: May 25, 2021

\subsection{3/repam.2021.3}

\section{How to cite}

Dorji, T. (2021). Content Analysis of

Entrepreneurship Education in Primary and Secondary School Textbooks. Research in Educational Policy and Management, 3(1), 42-59.

\section{https://doi.org/10.46303/repam.2021.3}

\section{Copyright license}

This is an Open Access article distributed under the terms of the Creative Commons Attribution 4.0 International license (CC BY 4.0).

\begin{abstract}
Textbooks are the main source of teaching-learning materials used in primary and secondary schools. This study was carried out in Bhutan to examine if the existing textbooks in primary and secondary schools contain sufficient knowledge and skills in entrepreneurship education. This descriptive study collected 96 textbooks used by students and teachers in classes PrePrimary (PP) to XII. The reviewers identified descriptions about entrepreneurship if any in the content and the pedagogical aspects. The content included the meaning of entrepreneurship, characteristics, student activity and images on entrepreneurship. The study revealed that entrepreneurship education is not thoroughly integrated into primary and secondary school textbooks. Three (3.1\%) out of 96 textbooks contained descriptions about entrepreneurship. The study, therefore, recommends existing textbook contents and images on entrepreneurship education to be improved and experiential learning opportunities be included. Ministry of Education and the Royal Education Council needs to review and revise classes PP-XII existing school textbooks at various levels. Integrate entrepreneurship education-related topics in the existing textbooks of primary and secondary schools based on the current labour market needs. However, Media Information Literacy, Environmental Science, and Agriculture for Food Security textbooks were not analyzed since many schools did not offer these elective subjects due to no or poor ability rating for higher education admission in Bhutan.

KEYWORDS

Entrepreneurship; entrepreneur; employment; textbook; school.
\end{abstract}




\section{INTRODUCTION}

Over the last two decades, employment opportunities in Bhutan changed dramatically. The high rate of youth unemployment was one of the most pressing issues among many others. Youth unemployment was estimated at 11.9 percent (NSB, 2019). The average unemployment rate has been between 3-4 percent annually. The female unemployment rate was higher than the male unemployment rate. Unemployment was more in the age of 15-24 years. According to the Ministry of Labour and Human Resources [MoLHR] (2019), most unemployed youths were found after the completion of middle secondary school and higher secondary school with 24.0 percent and 28.5 percent respectively. According to the National Statistics Bureau [NSB] (2019), the unemployment rate of youth was four times more than the unemployment rate of the adult in 2019.

Youth high rate of unemployment was one of the growing concerns of the government. The growing unemployment rate can engender social issues and has economic implications. Youth unemployment means the lost talent and opportunity, loss of earning, compromising needs, and goals of youth. In many cases, youth were diverted to anti-social behaviour likely to get involved in illegal means or black market to earn living. The poor socio-economic condition and unemployment have a positive correlation to youths committing crimes and conflict with laws and orders (Gyeltshen, Namgay \& Minten, 2015). As a result, such a problem may lead to another problem dragging the state into an unending vicious circle of a problem and unending mess (Dash, Bakshi \& Vyas, 2016).

Bhutan's development philosophy of Gross National Happiness (GNH) judiciously balances material advancement and the spiritual well-being of its citizens as a result of economic growth. In 2010, the Educating for Gross National Happiness policy was introduced into schools. Educating for Gross National Happiness policy shifted an academically-oriented curriculum to happiness as the key goal of education (Gyamtsho, Sherab \& Maxwell, 2017). Education is included as one of the nine domains of GNH (GNHC, 2013). Such aspirations of the government cannot be achieved if the youth unemployment rate in Bhutan is not addressed within timebound.

The high rate of unemployment is a result of a high number of drop-outs from classes ten and twelve who do not qualify for higher education. Students look down upon blue colour jobs and therefore many classes ten and twelve graduates remain unemployed (iDiscoveri Education \& REC, 2009). It was projected that during the $12^{\text {th }}$ Five Year Plan (2018-2023), 62,743 youth would enter the labour market. Among the unemployed, many youths have the potential of remaining self-employed (REC, 2019).

Since the prospect of expanding employment in civil service and corporate organizations were limited, youth were forced to join private organizations or remain self-employed. The Royal Civil Service Commission of Bhutan targets to maintain a small, compact, and efficient civil service (RCSC, 2018). There was limited demand for labour in the public and private sectors 
while there was an excess supply of labour in the market (NSB, 2020). The growth of the private sector was too slow in Bhutan to employ the growing number of youth. Besides, the increasing enrolment rate in secondary schools has brought changes in the employment rate. The enrolment rate of school in 2019, 2018, and 2017 were 166786, 167108, and 168092 (MoE, 2019). According to NSB (2020), nearly 62,743 students will enter the labour market by the end of the Twelfth Five Year Plan. Without an adequate generation of employment opportunities, the unemployment rate among educated youth was expected to increase significantly.

The Sustainable Development Goal 8 calls for the "promotion of sustained, inclusive and sustainable economic growth, full and productive employment, and decent work for all" (GNHC, 2019). 20 percent of the population constitute youth (15-24 years).

Entrepreneurship was a driving engine for economic growth, economic competitiveness, and job creation (Dash, Bakshi \& Vyas, 2016). In Bhutan, the requirement and opportunity for entrepreneurs were high. According to Chauhan and Aggarwal (2017) entrepreneurship act as an economic developer and career option and finally boost economic empowerment and selfconfidence. Thus, entrepreneurship education-related topics were necessary and should be included in PP, primary and secondary school textbooks. The schools need to teach entrepreneurship skills and disseminate the information so that students can remain selfemployed after graduating from secondary schools.

Entrepreneurship subjects are becoming important in the $21^{\text {st }}$ century all around the world. The government gives the highest priority to ease the unemployment rate (NSB, 2020). By the end of the Eleventh Five Year (2013), the government created Overseas Employment Program with the aim of sending 30,000 youths to work abroad (Rabgyal, 2021). Currently, the government of Bhutan is breaking away from traditional stereotypic roles in promoting entrepreneurship among youth. According to Gurung and Tenzin (2018, p. 47) "entrepreneurship education has to start from the elementary to the university level, to train creative, innovative and productive citizens...". Textbooks have economic and ideological implications to boost youth entrepreneurship and address unemployment issues.

\section{Objective of the Study}

The study aimed to examine the existing primary and secondary school textbooks contain entrepreneurship knowledge and skills to promote and support entrepreneurship or selfemployment in Bhutan.

\section{Significance of the Study}

The study was significant to draw policy and curriculum attention. The study would be useful to policy-makers, curriculum developers, teachers, students and other relevant stakeholders. The study would also be useful for other researchers to carry out comprehensive studies on this similar interest and issues. 


\section{Research Question}

Do the existing textbooks for primary and secondary schools contain entrepreneurship content to promote entrepreneurship among the Bhutanese youth?

\section{LITERATURE REVIEW}

The available literature shows a variety of definitions for entrepreneurship by different scholars. However, the definitions are found fundamentally similar. The word entrepreneur was taken from the French word 'enterprendre' meaning to undertake. Entrepreneurship is the act of being an entrepreneur (Desai, 1999), a dynamic process of vision, change, and creation (Gairola, 2019; NSB, 2020), and a process of designing a new business offering product, process, or services (REC, 2018). According to Global Entrepreneurship Research Association (2013) entrepreneurship is any attempt at new venture creation or new business, such as selfemployment, or a new business organization, or the expansion of business by an individual or a group. Entrepreneurship is an act of starting a new venture associated with responsibilities and risks (Chauhan \& Aggarwal, 2017).

The entrepreneur is the person who has the will and ability to transform mere invention and idea into novelty and innovation (Chauhan \& Aggarwal, 2017). Entrepreneurs create new jobs, drive business, and play important role in the economy (Gairola, 2019). Entrepreneurs apply innovation, arrange resources and finance, and transform innovation into economic goods. Entrepreneurs are risk-taking, creative, innovation, and goal-oriented.

Today, any student who has an entrepreneurial mindset and attitude can pursue a business or remain self-employed. The entrepreneurial mindset is characterised by seeing and creating opportunities, turning ideas into action, leading the way, using resources smartly, managing risks, and collaborating to create shared values (Gurung \& Tenzin, 2018).

Although the future is uncertain, however, future employment opportunities will be driven by innovation and entrepreneurship. It is important to develop adequate entrepreneurial skills, attitudes, mindset and behaviours in the students. Unfortunately, many students learn entrepreneurship skills on their own after they graduate from school and university (Gairola, 2019) although a large number of student schools have the potential of developing entrepreneurship skills. Willingness to take calculated risks of time, career, equity, creative skills to organize resources, team forming, skills in building a business plan, recognize opportunity instead of contraction, chaos, and confusion are some of the essential attributes in entrepreneurship education (Kuratko \& Hodgetts, 2004).

Developing entrepreneurial skills will be one way of reducing unemployment. In the study by Uka (2015) entrepreneurship skills holistically address the issue of unemployment. Besides, it prepares students for self-employment and financial independence. Schools have a bigger role to play in developing an entrepreneurship thriving society. Schools can change the mindset and attitude of students to start entrepreneurship ventures (Manuere, Danha, \& Majoni, 2013). Involving children in entrepreneurship involves engaging them in accounting, 
finance, marketing, human resource management, and the population productively. Successful entrepreneurship is possible if students possess the main characteristics of entrepreneurs such as, a desire to start their enterprises and the readiness to undertake any scheme (Zimmerer, 2008).

The mindset and attitude of youth towards entrepreneurship varies from country to country. In developed countries such as Canada, most youth would start their enterprises someday (Green \& Pryde, 1990). However, in Bhutan, the students' view of entrepreneurship is a serious concern. University graduates are not interested to start their own business rather many have the ambition to get a salaried job in the government or corporation after completion of their education. Employment in a private organization and starting a business is the last option (Rizvi, 2017). Similarly, for university students in Bhutan, entrepreneurship is not the first option. According to NSB (2020) a majority of youth preferred civil service the most for employment choice than other enterprises in Bhutan. Entrepreneurship in Bhutan is viewed as the last resort instead of taking it as an opportunity or aspiration (Utha, et al., 2016; Gurung \& Tenzin, 2018). Unfortunately, many aspiring youths were unable to find a job in civil service and corporate organizations (NSB, 2020).

In many African countries, entrepreneurship education is lacking in the education systems. Due to a lack of a broad knowledge base, the youth were unaware of data making, pricing strategies, market forces, and predict market trends (Dash, Bakshi \& Vyas, 2016). The entrepreneurial culture is new in Bhutan and requires adjustment in the mindset and attitude. Utha et al. (2016) revealed that there was minimal focus on entrepreneurship education in the schools, higher education curriculum, and pedagogical practices. The study recommended the inclusion of entrepreneurship education in the secondary school curriculum. Introducing entrepreneurship into the national education system would prepare students for an entrepreneurship career by imparting skills, knowledge, and aptitude for entrepreneurship. Kruegar and Brazeal (1994) suggest preparation as the key element for creating potential entrepreneurs to take up opportunities. Thus, analysing the entrepreneurship education content in the existing textbooks used in PP, primary and secondary schools is crucial to address youth unemployment and to promote and support entrepreneurship or self-employment in Bhutan.

\section{METHODS}

This study used a descriptive approach to analyse the content (Nonaka et al., 2012). The content analysis includes examining entrepreneurship education concept, facts, ideas, figure, learning activities and images used in the Bhutanese PP, primary and secondary school textbooks (Zhang \& Barbara, 2016; Solikhak, 2020).

\section{Textbook collection}

In Bhutan, school education comprises primary school (class PP-VI), lower secondary school (class VII-VIII), middle secondary school (class IX-X), and higher secondary school (class XI-XII). 
In primary school, Dzongkha (national language), English, Mathematics, Social Studies, Environmental Studies, Health and Physical Education and Arts Education, Science were taught.

In the lower secondary school, students study Dzongkha, English, Mathematics, Integrated Science, History, Geography, Information Communication, and Technology.

In middle secondary school, students study Dzongkha, English, Mathematics, Physics, Biology, Chemistry, History and Civics, Geography, Information Communication and Technology, and Economics.

At the higher secondary school, students can opt for arts, commerce, or science streams based on their academic performance in middle secondary school. The arts stream includes Dzongkha, English, Mathematics, Economics, Geography, History, and Civics. The commerce stream includes Dzongkha, English, Mathematics, Accountancy, Economics, and Commerce. The science stream includes Dzongkha, English, Mathematics, Physics, Biology, and Chemistry.

The study collected a total of 96 textbooks used in primary, lower secondary, middle secondary, and higher secondary school. In Bhutan, all textbooks were developed by the REC.

Textbooks in Bhutanese schools are the only reliable resource for teaching-learning materials. Assessment is also driven by the textbook content because mastery of the content of the textbooks is what is assessed. Teachers have limited knowledge of exploring other sources and connecting to the main topics taught in the school. The overall orientation of the education system holds teachers to naturally refer to textbooks as the source of information, content to be taught, content to be assessed and enhance mastery of content materials by students.

\section{Textbook examination}

The study reviewed the textbooks and identified descriptions about entrepreneurship by seeking the term "entrepreneur "or "entrepreneurship". Non-English descriptions were translated into English. The second reviewer checked the findings of the first reviewer to overcome the narrow or biased interpretation of data (Nonaka et al., 2012). In case of a discrepancy, both reviewers sat together and re-examined the topic for common solutions.

\section{Content analysis}

The study categorized the descriptions of textbooks following the content of the descriptions and student activity. The content of the topic in textbooks included the meaning of entrepreneurs, the role of entrepreneurs, characteristics of entrepreneurs, entrepreneurship and economic development, ways to promote entrepreneurship, examples of entrepreneurship and images of entrepreneurship.

\section{Image analysis}

"A picture is worth a thousand words", therefore, image analysis was carried out to support content analysis. Image analysis included what kind of entrepreneurship approach was reflected in the textbooks. 


\section{FINDINGS AND DISCUSSION}

\section{Textbooks Examination}

Out of 96 textbooks, three (3.1\%) textbooks contained descriptions about entrepreneurship or entrepreneurs. The entrepreneurship-related topics were found in Economics and Commerce. None of the other textbooks used in primary and lower secondary schools contains entrepreneurship-related topics. The textbooks were not of the latest editions with current information and graphics. The primary and lower secondary school textbooks focused on developing basic entrepreneurship skills such as communication and numeracy. The middle secondary school Economics textbooks included few entrepreneurship concepts, learning activity and images.

The textbook analysis revealed the absence of a continuation of topic entrepreneurship concepts from class nine to twelve in Economics textbooks. The entrepreneurship content does not have sequences and it would have been difficult for teachers and students to create students' interest. The higher secondary accountancy textbooks discussed only corporate and organization business. Reasoning, creating, and application of entrepreneurship knowledge was not emphasized in the textbooks.

\section{Content analysis}

Schools in Bhutan do not teach entrepreneurship as a separate subject in schools. Entrepreneurship education was also not thoroughly integrated into primary and secondary school textbooks. Textbooks that contain topics on entrepreneurship are only those of class IX and $X$ Economics. In case if students do not opt to study Economics in classes nine and ten, students would have never learnt about entrepreneurship in the school. According to the Bhutan Council for School Examinations and Assessment (2021) 12, 614 students sat for the Bhutan Certificate of Secondary Education Examination, of which only 2,677 sat for economics in 2019. Thus, most students do not have entrepreneurship education and economic literacy. Textbooks used in PP to class eight predominantly cover topics through which students can learn basic numeracy and literacy skills.

The entrepreneurship content available in the class nine Economics textbooks is not seen to be built upon in the content of the class ten textbook. Thus, a continuation of learning is missing for students. Of the three textbooks that contained entrepreneurship descriptions, it dealt with the meaning of entrepreneurs, their role, enrolment trend in Bhutan as shown in Figure 1, 2 and 3: 


\title{
Entrepreneur
}

A person who organizes the production of goods and services by combining several factors of production is called an entrepreneur.

Figure 1. Definition of Entrepreneur

Source: Economics Class IX (REC, 2019, p.15)

\begin{abstract}
Entrepreneur
The word entrepreneur is derived from the French word 'entreprendre', which means 'to undertake'. The word was originally used to describe people who 'take on the risk' in business or who 'undertake' a task such as starting a new venture.

Entrepreneurs are those who organise and combine all the factors of production to produce goods and services in an economy. They take important decisions regarding production and bear the risks involved in production. Successful entrepreneurs are rewarded with profit.

Entrepreneurs have certain common characteristics such as passion, self-confidence, creativity and the ability to confront challenges. They are ready to take risks and are willing to learn new things. Entrepreneurs are also self-reliant as they are self-supportive and independent. They are self-starters who do not wait for others to tell them what to do. While they may actively compete with others, they also constantly try to improve their own performance and competence.

In addition, the success of an entrepreneur is supplemented by skills such as planning, communication, marketing, interpersonal, basic management, leadership, team building and ICT skills.
\end{abstract}

Figure 2: Entrepreneur

Source: Economics Class IX (REC, 2019, p.16-17)

There are few essential attributes of entrepreneurs in the textbook as shown in Figure 2. The class IX and X Economics textbooks did not specify either the entrepreneurship roles in the $21^{\text {st }}$ century or highlight entrepreneurship mindset and entrepreneurship culture. There is limited opportunity for experiential, discovery, inquiry-based learning, and a lack of living examples, applications and learning. The entrepreneurship education content, learning activity, images and experiential learning in textbooks will have a large impact on entrepreneurship knowledge and skills development in the long run. 


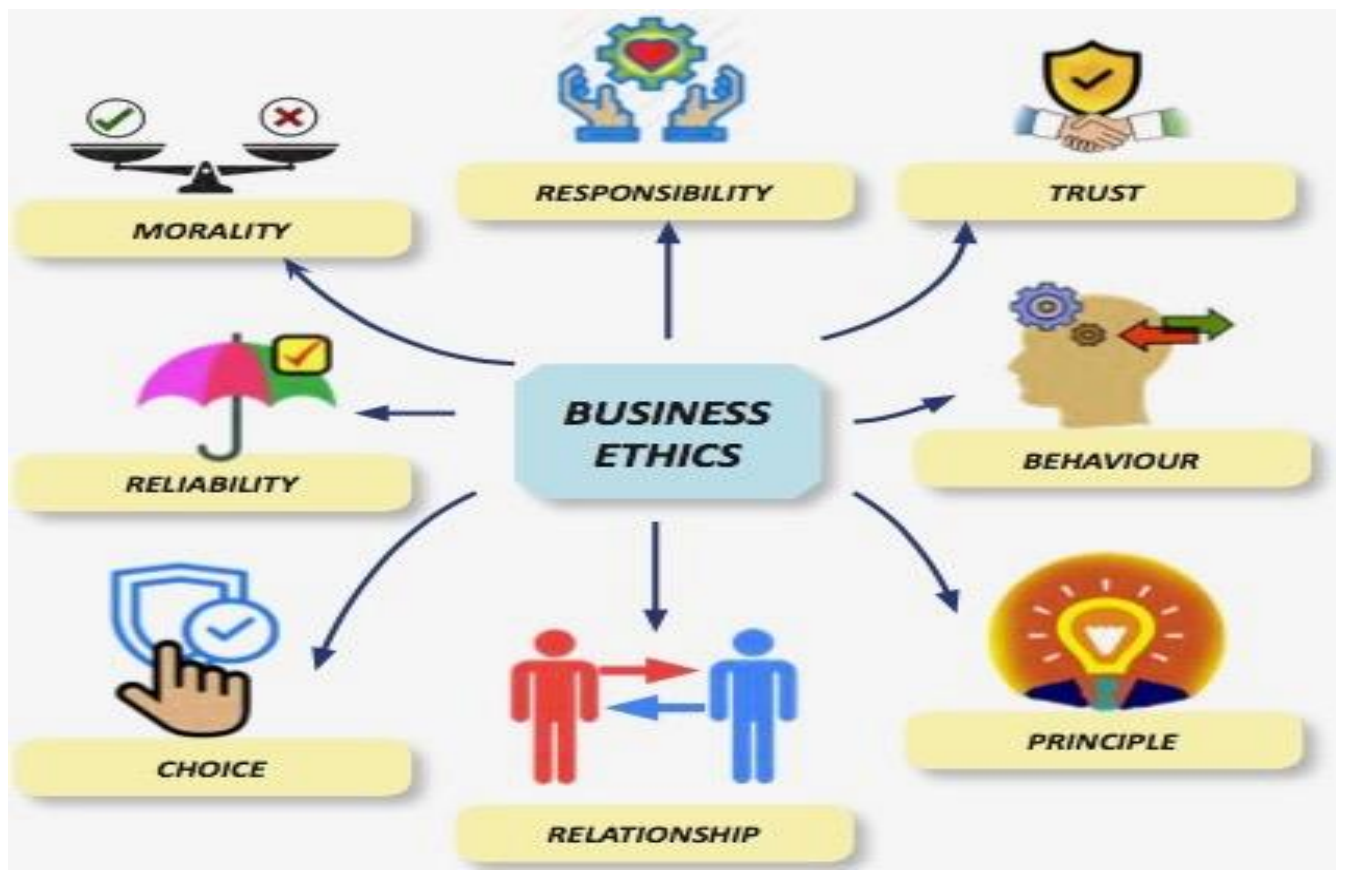

Figure 3: Business Ethics

Source: Economics Class X (REC, 2020, P. 25)

The ethical business practice has been outlined in the class ten Economics textbook as shown in Figure 3 to mystify the myth and traditional belief of entrepreneurship being a practice of just making profits and cheating customers.

\section{Employment trends in Bhutan}

The employment scenario in Bhutan has undergone major changes, particularly over the last two decades. This is an outcome of the country's transition from a subsistent agrarian economy to a modern economy with a faster growth rate in the secondary and tertiary sectors against the primary sector. In the past, the vast majority of the population was concentrated in the primary sector. However, with the development, the percentage of the population working in the agricultural sector has declined from about $90 \%$ in 1980 to about $44 \%$ in 2010 indicating economic progress.

The percentage of those employed in secondary and tertiary sectors has increased, representing a shift to the secondary and the service sectors away from the primary sector. The secondary sector in 2005 accounted for $17 \%$ of the total number of employed labour forces tripling from less than $5 \%$ in 1999 . Similarly, the share of the total employment accounted for by the service sector increased to $39 \%$ in 2005 from $16 \%$ in 1999. This is not only explained as an outcome of the modernization of the economy from its subsistence agriculture base but can also be attributed to the rural-urban migration trends and accompanying population shifts. 
With this growth, the phenomenon of unemployment which was unknown before became a major problem. The unemployment rates have increased from $3.2 \%$ in 2006 to $4 \%$ in 2009. In classifying the employment data further, there are concerns related to female unemployment which became much higher than that of male. The National Labour Force Survey 2006 reflects that female unemployment rates are higher with $3.8 \%$ than that of male with $2.6 \%$ respectively.

Among the unemployed, many youths have the potential to be self-employed. The number of people starting small businesses is increasing every year. The government has also been developing strategies to promote and support self-employment and entrepreneurship. Some measures to promote self-employment include encouraging banks to expand credits, conducting special training on entrepreneurship, skill development, providing proper guidance and mentoring to the individual.

Figure 4: Employment Trends in Bhutan

Source: Introductory Economics, A Course Book for Class X (REC, 2019, p.14)

Figure 4 shows that textbooks were not updated and do not have provoking recent case studies and current information. According to Gurung and Tenzin (2018) promoting entrepreneurship is advantageous in promoting creativity and innovation, increase national income, produce new products and services, and new business, bring about balanced regional development, generate employment, help dispersal of economic power, and enhancing welfare amenities and improved standard of living. Characteristics of entrepreneurship, such as mindset: turning ideas into actions, seeing and creating opportunities, using resources smartly, leading the way, managing risk, and collaborating to create shared value could have been integrated into the content of the textbook. The textbooks do not cover elements of entrepreneurial culture such as value creation through innovation and change, people and empowerment focused, attention to the basics, freedom to grow and fail, hands-on management, emphasis on the future, and sense of urgency, and commitment and personal responsibility (Gurung \& Tenzin, 2018) to encourage entrepreneurial mindset. It is important to mention the startup initiatives and incubator projects in Bhutan.

Student activity could include problem-based, project-based, place-based and inquirybased approaches so that there is a deeper understanding of entrepreneurial possibilities and generate interest in students. Students could be taught business proposal writing and schoolbased or school club activity-based micro-business projects could be encouraged and supported by the schools. Entrepreneurship seminars and fairs could be organized at the school or when there are national and local trade fairs are held, schools should facilitate for students to attend. 


\section{Learning Activity 2.6: Surveying business ethics}

\section{Instructions:}

1. Plan and prepare a field study in two groups to conduct interview with at least 15 retailers each in your locality.

2. Use the suggested questionnaire provided in the box to guide the interview.

\section{Business Ethics Survey Questionnaire}

A. General Information of the respondent
1. Sex:
2. Age:
3. Marital status:
4. Qualification:
5. Dzongkhag:

\section{B. Business Ethics}

\begin{tabular}{|c|c|c|c|c|c|}
\hline St. no & Particular & Aiways & Sometimes & Rarely & Never \\
\hline 1 & $\begin{array}{l}\text { Do you greet your customers when they come } \\
\text { to your shop? }\end{array}$ & & & & \\
\hline 2 & $\begin{array}{l}\text { Do you check the expiry date of the goods in } \\
\text { your shop? }\end{array}$ & & & & \\
\hline 3 & $\begin{array}{l}\text { Do you sell the autdated goods to your } \\
\text { customers? }\end{array}$ & & & & \\
\hline 4 & $\begin{array}{l}\text { Do you dump the expired products of your } \\
\text { shop? }\end{array}$ & & & & \\
\hline 5 & Do you charge your customers based an MRP? & & & & \\
\hline 6 & $\begin{array}{l}\text { Sometimes, some customers forget to take the } \\
\text { maney changes. } \\
\text { Do you give the changes back when the } \\
\text { customer cames to collect it later? }\end{array}$ & & & & \\
\hline 7 & $\begin{array}{l}\text { Do you produce the true business worth } \\
\text { through book of accounts while paying } \\
\text { business tax? }\end{array}$ & & & & \\
\hline 8 & $\begin{array}{l}\text { Do you refer custamers to ather shaps when } \\
\text { goods are not available in your shop? }\end{array}$ & & & & \\
\hline 9. & \multicolumn{5}{|c|}{ For how long have you been doing this business? ................... } \\
\hline 10. & \multicolumn{5}{|c|}{ Why did you choose this business? } \\
\hline 11. & \\
\hline & \multicolumn{5}{|c|}{$\begin{array}{l}\text { What is your approximate annual incame? } \\
\square \text { Less than Nu s0,000 } \square \text { Nu } 51,000-N_{4} 99,000\end{array}$} \\
\hline
\end{tabular}


3. Observe research ethics to avoid sensitive issues. Information collected should be for academic purpose only.

Answer the following questions

i) How does the following influence the business ethics?
a) Age
b) Sex
c) Marital status
d) Qualification

ii) Use bar graph to analyse the information of respondents in terms of
a) tax payment.
b) Maximum Retail Price.
c) sale of expired goods.

iii) Comment on the business ethics of the local retailers.

iv) What strategies can be used to raise the business ethics in the community?

v) How do you relate business ethics with our Bhutanese values of Tha Dam-tsig Ley Ju-drey?

\section{Figure 5: Images of entrepreneurship}

Source: Economics Class X (REC, 2020, p. 26-27)

There was one activity about entrepreneurship in class ten and nine Economics textbooks as shown in Figure 5 and 6 . The activity was not well thought to give room and opportunities for discovery and inquiry. International and local practices of entrepreneurship development have the potential to educate students to be global entrepreneurs. Therefore, case studies and scenarios from around the world would provide global perspectives and enrich learning. Projectbased learning involving the study of local entrepreneurs, their success and failure, motive, values, vision, and strategy could provide hands-on experiences of understanding entrepreneurship development in Bhutan. It was also important for primary and secondary school to inculcate entrepreneurial culture and competencies through entrepreneurship education from an early stage (Gurung \& Tenzin, 2018). 


\section{Learning Activity 3.2}

1. Plan and prepare a field study in your respective teams to carry out an interview with an entrepreneur in your locality.

Use the questionnaire provided below to interview an entrepreneur.

\section{Entrepreneur's profile and questions}

Name of the entrepreneur:

Nature of the venture:

Location:

Year of establishment:

a. What made you start this venture?

b. What were some of the challenges you faced when starting your venture?

c. How did you overcome those challenges?

d. What are some of the current challenges and how do you overcome them?

e. What are your strengths or weaknesses as an entrepreneur?

f. Do you have any plans to expand your business?

g. What advice would you give to youths who want to become entrepreneurs?

2. Based on the information obtained from the interview, mention some of the characteristics that enable the person to be a successful entrepreneur.

3. If you aspire to be a successful entrepreneur, what are the traits do you need to possess and which are the ones that you need to acquire?

4. Discuss the role of an entrepreneur in the economic development of a country like Bhutan.

5. Do you believe that entrepreneurs are 'born' and not 'made'? Justify your answer.

Figure 6: Entrepreneur

Source: Economics Class IX (REC, 2019, p.17-18) 

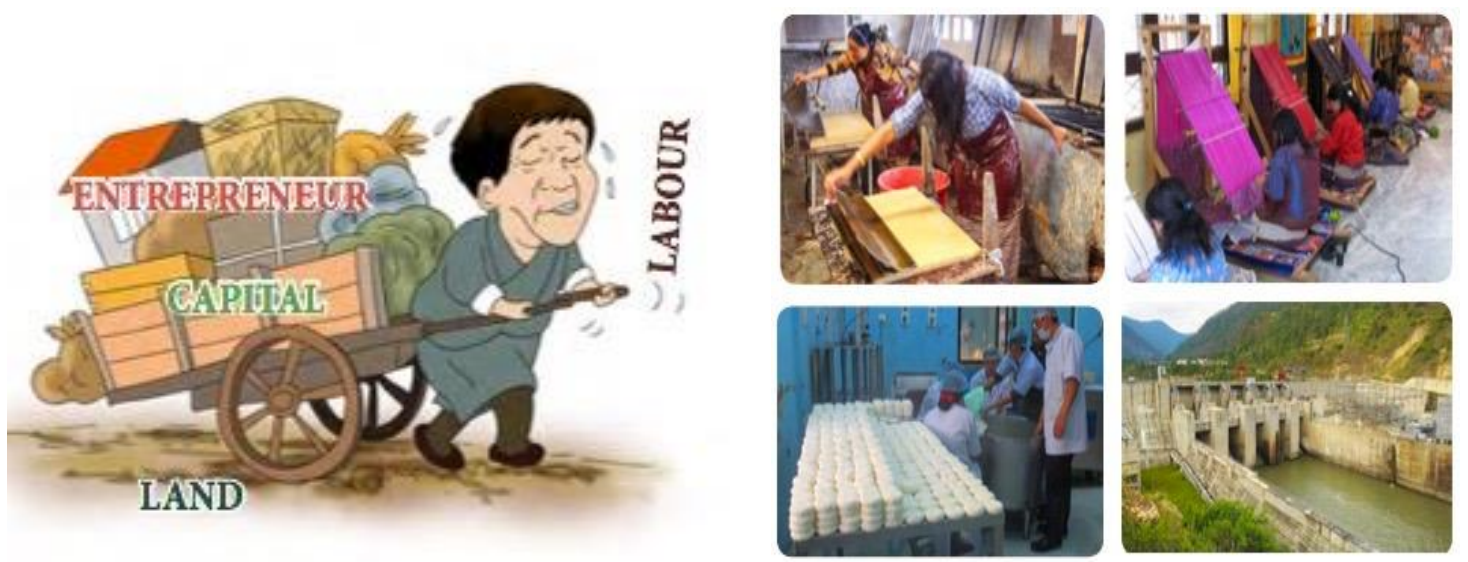

Figure 7: Images of entrepreneurship

Source: Economics Class IX (REC, 2019)
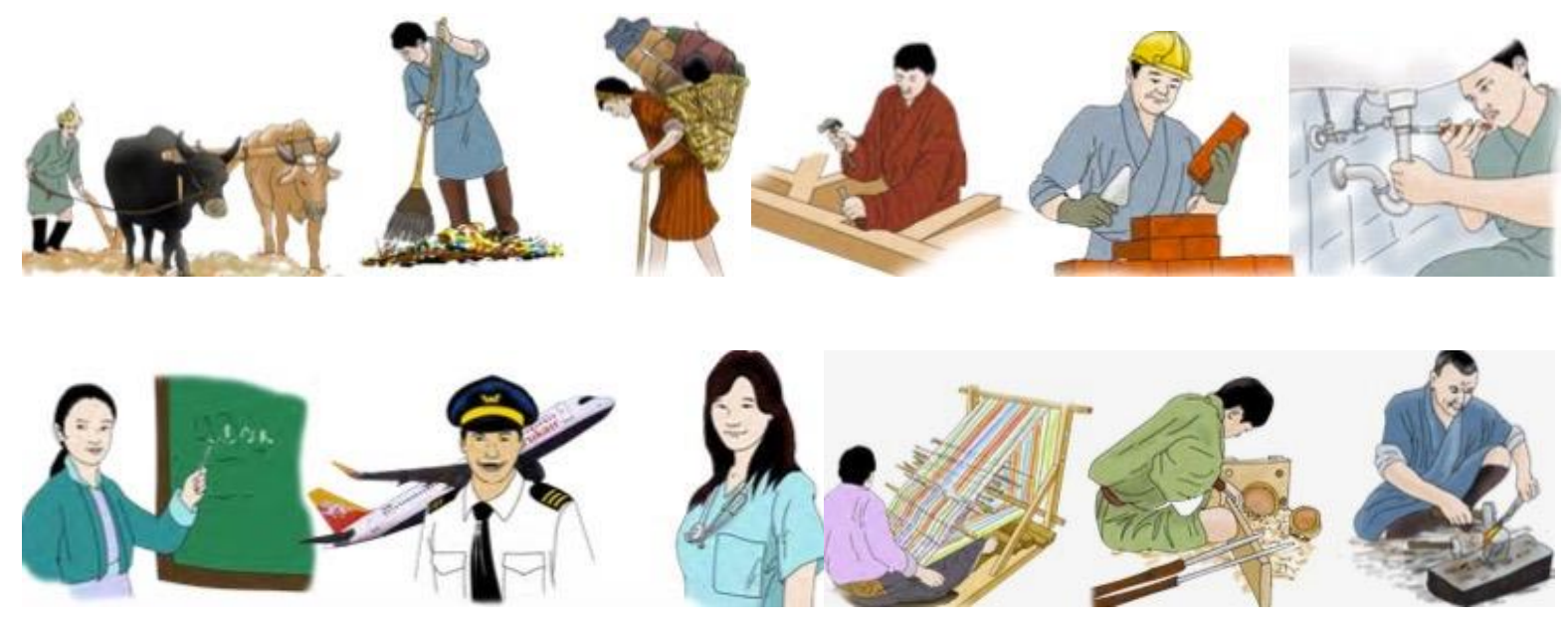

Figure 8: Images of entrepreneurship

Source: Economics Class X (REC, 2020)

The images portrayed in Figures 7 and 8 from the Economics textbooks of class IX and X show a poor illustration of entrepreneurship through images. The images display gender stereotypes and do little to reinforce the positive sense of entrepreneurship. Although UNESCO (2004), explains gender stereotypes as undermining the quality of education, textbooks which are chief materials of education in schools still show evidence of unconvinced demerits and implied principles in the textbooks (Yuden, Chuki \& Dorji, 2021).

The images on entrepreneurship can be inspiring to reflect and set examples to become entrepreneurs, create employment opportunities and boost the country's economy. The images need to convey the message that an entrepreneurship career was meant for both man and 
women. Policymakers and curriculum developers should be sensitive to stereotyping contents in textbooks (Yuden, Chuki \& Dorji, 2021). The primary and secondary school textbooks need to incorporate robust entrepreneurship education in the Bhutanese context. The existing school textbooks do not deliver the right skills for the job markets. There would be limited job opportunities in the market by 2030 with the current pace of development. The unemployment rate in the market kept increasing year after year. If policymakers and curriculum developers do not start reforming textbooks now, it would be too late later to ease unemployment issues in near future.

The 21st century demands students to be the entrepreneurial generation with skills such as critical thinking, creativity, collaboration, communication and competencies (Gairola, 2019). The textbooks will have to go beyond the domestic standards to be able to avail job opportunities beyond the country.

The future of work is uncertain in many cases however the demand for entrepreneurship would remain more than ever before. Entrepreneurial education in schools will lead to the development of entrepreneurial competencies of knowledge, skills and attitudes that affect the willingness and ability to perform the entrepreneurial job of new value creation (Lackeus, 2015).

There were 94,165 students in primary school, 25, 299 students in lower secondary schools, 26,813 students in middle secondary school and, 24,529 students in higher secondary school (MoE, 2020). There is a need for improvement of existing primary and secondary school textbooks content about entrepreneurship education. Educating students early from the PP level, on the importance of entrepreneurship, the concept of entrepreneurship will be natural and can be reinforced message throughout the schooling course. Education on entrepreneurship has to continue at an early age. This will change the mindset and attitude of the students. Education is a powerful weapon to change the mindset and attitude of entrepreneurship (NECS, 2019).

The findings and discussion corroborate with Utha et al. (2016) who found minimal focus on entrepreneurship education in the schools, higher education curriculum, and pedagogical practices.

\section{CONCLUSION AND RECOMMENDATION}

Based on the findings and discussion, the existing PP, primary and secondary textbooks contain minimal knowledge and skills on entrepreneurship. The textbooks address the meaning of the entrepreneur, the role of the entrepreneur, business ethics and it rarely addresses the entrepreneur mindset and culture among others. Through this study, it was discovered that the current textbooks play a limited role in promoting entrepreneur education to teachers and students. Improving PP, primary and secondary school textbook content and images with entrepreneurship is necessary. Reasoning, creating, and application of entrepreneurship knowledge was not much emphasized in the textbooks. The entrepreneurship content available in the class IX Economics textbooks is not seen to be built upon in the content of the class $X$ 
textbook. Thus, a continuation of learning was missing for students. There are limited opportunities for experiential, discovery, inquiry, and student-centred learning. Activities were few, not varied and not well thought out to generate teacher and student curiosity and interest.

To achieve wholesome education and address the unemployment issue and to improve self-employment in Bhutan, the MoE and the REC should consider implementing the following:

- the current PP, primary and secondary textbooks need to be revisited, reassessed and re-evaluated at various levels. Integrate entrepreneurship education-related topics in the existing textbooks of PP, primary and secondary schools based on the current labour market needs. Textbooks are a powerful tool to break stereotypes. Primary and secondary schools should teach youth aspects and prospects of entrepreneurship.

- organize mounting workshops, seminars and conferences on entrepreneurship education for teachers, parents, students, curriculum developers, and policymakers aimed at changing their mindset and attitude towards government or corporate jobs and remain self-employed.

Without revisiting the existing textbooks, all amounts of research will not significantly impact the larger goal of easing unemployment and self-employment. Unless this is realized, Bhutan will remain far from easing the unemployment rate and self-employment in the future. Schools need to teach entrepreneurship education from elementary or PP to higher education for creative, innovative and productive future citizens of the country. Entrepreneurship education has the potential to change mindset, attitude and foster entrepreneurship among student and the community. Thus, entrepreneurial education needs to be seen as part of a larger societal employment opportunity.

\section{Limitation of the Study}

Media Information Literacy, Environmental Science, and Agriculture for Food Security textbooks were not analysed since these subjects are elective in many schools and these subjects scored no or low ability rating for higher education admission in Bhutan.

Further study is necessary to assess the accuracy of content about entrepreneurship in PP, primary and secondary school existing textbooks. For better findings, future researchers are recommended to adopt a mixed-method approach comprising of a survey questionnaire for parents, students, teachers, and policymakers. Interviews and focus group discussions with the same groups of participants are recommended. The sample for the study should be equally distributed among the four regions of the country for better representation. A similar study could also be done on higher education textbooks or modules in Bhutan.

\section{REFERENCES}

Bhutan Council for School Examinations and Assessment. (2021). Pupil Perormance Report 2020: Volume 13. Thimphu, Bhutan: Bhutan Council for School Examinations and Assessment. 
Chauhan, K., \& Aggarwal, A. (2017). Youth Entrepreneurship: The Role and Implications for the Indian Economy. Amity Journal of Entrepreneurship, 1(2), 23-33.

Dash, M., Bakshi, S., \& Vyas, V. (2016). A comparison of Entrepreneurial Competencies of Young Women and Men in India. Amity Journal of Entrepreneurship, 2(2), 1-11.

Desai, V. (1999). Dynamics of Entrepreneurial Development and Management (3rd ed.). India, Mumbai: Himalaya Publishing House.

Gairola, R.S. (2019). Attitudes of Secondary teacher trainees towards entrepreneurial education. Research in Educational Policy and Management, 1(1), 44-54.

GNHC. (2013). Eleventh Five Year Plan Document. Thimphu, Bhutan: GNHC.

GNHC. (2019). Twelfth Five Year Plan 2018-2023: Just, Harmonious and Sustainable Society through Enhanced Decentralization. Thimphu, Bhutan: GNHC.

Gairola, R. S. (2019). Attitudes of secondary teacher trainees towards entrepreneurial education. Research in Educational Policy and Management, 1(1), 44-54.

Global Entrepreneurship Research Association. (2013). Global Entrepreneurship Monitor 2012 Report. Retrieved from http://www.gemconsortium.org/docs/download/2645

Green, S., \& Pryde, P. (1990). Black entrepreneurship in America. New Brunswick, NJ: Transactions Publishing.

Gurung, R.B., \& Tenzin, J. (2018). The Entrepreneurship Culture. The Druk Journal, 4(2), 43-55.

Gyamtsho, D. C., Sherab, K., \& Maxwell, T.W. (2017). Teaching learning in changing professional contexts: Bhutanese teacher educators and the Educating for GNH initiative. Cogent Education, 4, 2-19.

Gyeltshen, S., Namgay, P., \& Minten, T. (2015). The Analysis of Reported Crime Among Young People in Bhutan. In L. Dorji, S. Gyeltshen, C. Jamtsho, T. Minten, P. Namgay, T. Dorjee, \& T. Wangchuk, Crime and Mental Health Issues Among the Young Bhutanese People (p. 149). Thimphu, Bhutan: National Statistics Bureau.

iDiscoveri Education \& REC. (2009). The Quality of School Education in Bhutan: Reality and Opportunities. Thimphu, Bhutan: REC.

Kuratko, D.F., \& Hodgetts, R.M. (2004). Entrepreneurship: Theory, Process, Practice. Manson: South-Western Publisher.

Kruegar, N., \& Brazeal, M. (1994). Entrepreneurship Intention: applying the Theory of Planned Behaviour. Entrepreneurship and Regional Development, 5(4), 315-30.

Lackèus, M. (2015). Entrepreneurship in Education: What, Why, When, How. Paris, France: Center for Entrepreunership, OECD.

Manuere, F., Danha, K., \& Majoni, T. (2013). Entrepreneurship Attitude and Knowledge: A Survey of Fourth Year University Students. Interdisciplinary Journal of Contemporary Research in Business, 4(9), 511-521.

MoE. (2019). Annual Education Statistics 2019. Thimphu, Bhutan: MoE.

MoE. (2020). Annual Education Statistics 2020. Thimphu, Bhutan: MoE. 
MoLHR. (2019). Labour Market Information Bulleting 2019. Thimphu, Bhutan: MoLHR.

NECS. (2019). National Waste Management Strategy 2019. Thimphu, Bhutan: National Waste

Management Strategy

NSB. (2019). Labour Force Survey. Thimphu, Bhutan: NSB.

NSB. (2020). Determinants of Youth Unemployment in Bhutan. Thimphu, Bhutan: NSB.

Nonaka, D., Jimba, M., Mizoue, T., Kobayashi, J., Yasuoka, J., Ayi, I., Jayatileka, A.C., Shrestha,

S., Kikuchi, K., Haque, S.E., \& Yi, S. (2012) Content Analysis of Primary and Secondary

School Textbooks Regarding Malaria Control: A Multi-Country Study. PLoS ONE, 7(5),

e36629. doi:10.1371/journal.pone.0036629

Rabgyal, D. (2021). Forces Shaping Bhutan's Young Social Capital. The Druk Journal, 7(1),

118-126.

RCSC. (2018). Bhutan Civil Service Rules and Regulations. Thimphu, Bhutan: RCSC.

REC. (2018). Environmental Science Class 11. Paro, Bhutan: REC.

REC. (2019). Economics Class IX. Paro, Bhutan: REC.

REC. (2019). Introductory Economics: A Couse Book for Class X. Paro, Bhutan: REC.

REC. (2020). Economics Class X. Paro, Bhutan: REC.

Rizvi, S.N.F. (2017). MBA Education and Entrepreneurship Development in India. Journal of

Management Science, Operations \& Strategies, 1(2), 18-28.

Solikhak, I. (2020). Evaluating EAP Textbooks for Indonesian University Students Using Impressionistic and In-depth Assessment. Indonesian Journal of English Language Teaching and Applied Linguistics, 4(2), 395-411.

UNESCO. (2004). A training manual for sensitizing education managers, curriculum and material developers and media professionals. France: UNESCO.

UNESCO. (2009). Promoting Gender Equality through textbooks: A Methodological Guide. France: UNESCO.

Uka, N.K. (2015). Developing Entrepreneurial Skills in Secondary School Students Through Effective Mathematics Education in Aba, Nigeria. International Journal of Education, Learning and Development, 3(7), 1-11.

Utha, K., Rinchen, S., Gurung, B., Gurung, G., Rabgay, T., \& Dorji, C. (2016). Entrepreneurship Education in Bhutan: Perception, Culture and Challenges. World Journal of Educational Research, 3(2), 460-501.

Yuden, Y., Chuki, S., \& Dorji, T. (2021). Gender Sensitivity in Textbooks in Secondary Education in Bhutan. European Journal of Educational Technology, 4(1), 14-30.

Zhang, Y., \& Barbara, W. (2016). Qualitative Analysis of Content. Retrieved from https://www.semanticscholar.org/paper/Qualitative-Analysis-of-Content-by-Zhang Wildemuth/b269343ab82ba8b7a343b893815a0bae6472fcca.

Zimmerer, T. W., \& Scarborough, N. M. (2008), Essentials of Entrepreneurship and Small Business Management. New York, USA: Person Prentice Hall. 